\title{
Detection of rainbow trout antibody to Egtved virus by enzyme-linked immunosorbent assay (ELISA), immunofluorescence (IF), and plaque neutralization tests $(50 \%$ PNT $)$
}

\author{
N. J. Olesen, N. Lorenzen, P. E. V. Jørgensen \\ National Veterinary Laboratory, Hangevej 2, DK-8200 Århus N, Denmark
}

\begin{abstract}
The humoral immune response to Egtved virus, the causative agent of viral haemorrhagic septicaemia (VHS) in rainbow trout Oncorhynchus mykiss, was investigated by means of the enzymelinked immunosorbent assay (ELISA), immunofluorescence (IF), and the $50 \%$ plaque neutralization test $(50 \%$ PNT). Sera from fish immunized with virus under aquarium conditions as well as sera collected from fish in farms with different VHS status were included in the experiments. ELISA proved to be more sensitive and less time- and material-consuming than either IF or 50\%PNT Using Elisa, antibody to Egtved virus was found in $54 \%$ of fish from infected trout farms examined while only $16 \%$ were positive by $50 \%$ PNT The IF test had a sensitivity close to that of ELISA, but was less suitable for examination of large numbers of sera. Non-neutralizing antibodies tend to persist longer after VHS infection than neutralizing antibodies. The kinetics of the antibody response was close to that previously published. No anamnestic immune response was observed with any of the tests. We conclude that our ELISA is well suited for VHS surveillance.
\end{abstract}

\section{INTRODUCTION}

The use of serological methods to survey for viral haemorrhagic septicaemia (VHS) in rainbow trout Oncorhynchus mykiss was made possible by the recent development of a sensitive plaque neutralization test (50\% PNT) for detecting neutralizing trout antibodies to Egtved virus, the causative agent of VHS (Dorson \& Torchy 1979, Olesen \& Jørgensen 1986a). Because the technique in question was relatively time-consuming (and thus unsuitable for examining large numbers of serum samples), attempts have been made to develop less time-consuming antibody detection methods of similar or higher sensitivity and specificity. The present report describes a modification of a previously developed immunofluorescence (IF) test (Jørgensen 1974) as well as a newly developed enzyme-linked immunosorbent assay (ELISA). The 3 techniques were compared by examining a number of sera from trout exposed to VHS under experimental or field conditions.

\section{MATERIALS AND METHODS}

Viruses and fish cell lines. Egtved virus, reference strain F1 (Jensen 1965), was cultivated and purified as previously described (Lorenzen et al. 1988).

Stock preparations of 2 F1-related low-passage isolates of Egtved virus, Gelsbro and Voldbjerg, and of the heat-adapted $F_{25}$ mutant strain of $F 1$ (de Kinkelin et al. 1980) were prepared in bluegill fry (BF-2) cells (Wolf et al. 1966) grown in Eagles MEM containing 10\% foetal bovine serum and Tris-HCL buffer and antibiotics in standard concentrations.

The spring viraemia of carp (SVC) virus (Fijan et al. 1971), a rhabdovirus, was included in the work to test the virus-specificity of the IF test. The SVC virus reference strain received from N. Fijan, Zagreb, Yugoslavia, was grown in EPC cells (Fijan et al. 1983) at $15^{\circ} \mathrm{C}$ as described for Egtved virus.

Antibodies and antibody conjugates. Antiserum to Egtved virus was prepared as follows: New Zealand 
white rabbits were given 5 injections of purified virus strain F1 over a period of 2 mo. For the first 3 injections, virus was mixed with equal parts of Freund's Incomplete Adjuvant (FIA). The immunization was then discontinued for a period of 2 mo and subsequently 3 injections were given over the following 6 wh period. For the first 2 of these injections, virus was mixed with FIA. The rabbits were bled $6 \mathrm{~d}$ after the last injection. A total of $1.6 \times 10^{10}$ tissue culture infective doses $50 \%\left(\mathrm{TCID}_{50}\right)$ of virus was given to each rabbit. Antiserum to rainbow trout IgM was prepared as previously described (Olesen \& Jørgensen 1986b). Immunoglobulin (Ig) from the rabbit antisera was purified by protein-A Sepharose affinity chromatography according to the supplier's (Pharmacia) insirucions. The purified ig from rabbit antiserum to trout IgM was conjugated to horseradish peroxidase (HRP) by the 2-step glutaraldehyde method described by Voller et al. (1979) and to fluorescein isothiocyanate (FITC) or tetramethyl rhodamine isothiocyanate (TRITC) according to the procedure given by Goding (1986). Monoclonal antibodies (MAbs) to rainbow trout IgM were kindly provided by Ann Thuvander, Swedish University of Agricultural Sciences, Uppsala, Sweden, and by Lisbeth Jensen, State Serum Institute, Copenhagen, Denmark. HRP-conjugated rabbit antiserum to mouse Ig was obtained from Dakopatts, Copenhagen.

Serum, complement, and plasma from trout. Serum and complement from rainbow trout were collected and prepared as previously described (Olesen \& Jørgensen 1986a). Plasma was obtained by stabilizing blood with 12.5 units heparin per ml followed by centrifugation for $20 \mathrm{~min}$ at $1000 \times \mathrm{g}$. Serum and plasma samples were heat-inactivated at $45^{\circ} \mathrm{C}$ for $30 \mathrm{~min}$ and stored at $-80^{\circ} \mathrm{C}$ until examined.

Sera from trout exposed to VHS under experimental conditions. Fifty rainbow trout of about $130 \mathrm{~g}$, originating from a VHS-free trout farm, were exposed to Egtved virus strain Voldbjerg by cohabitation with 7 fish showing clinical signs of VHS as previously described (Olesen \& Jørgensen 1986a). Blood samples were collected before the virus exposure. Four weeks later, the surviving fish $(70 \%)$ were individually tagged and blood samples collected at intervals of 2 wk during the following $23 \mathrm{wk}$. Fourteen weeks after the first exposure to virus, the surviving fish received an intraperitoneal injection of $10^{5} \mathrm{TCID}_{50}$ of Egtved virus strain Voldbjerg per fish. The water temperature in the aquaria was ca $10^{\circ} \mathrm{C}$ during the entire period.

Trout sera collected under field conditions. Serum samples were collected from 289 rainbow trout originating from 7 trout farms that had been free of VHS for several years (as verified by biannual VHSsurveillance by public fish health authorities) and from
115 rainbow trout originating from 4 trout farms known to be infected with Egtved virus.

$50 \%$ plaque neutralization test $(50 \% \mathrm{PNT})$. All serum samples collected in the study were examined by means of the $50 \%$ PNT, with complement addition and use of the $F_{25}$ Egtved virus strain, as previously described (Olesen \& Jørgensen 1986a). The 50\% PNT titre is given as the reciprocal value of the highest serum dilution causing $50 \%$ reduction of the average number of plaques counted in cultures containing normal trout serum, virus, and complement.

Immunofluorescence (IF) test. All serum samples from fish that survived the aquarium experiment were examined by IF, as well as by $50 \%$ PNT and ELISA, as follows: Coverglass cultures, $9 \times 22 \mathrm{~mm}$, of EPC cells were infected with $1 \times 10^{\circ} \mathrm{TCID}_{50}$ per $\mathrm{ml}$ of Egtved virus strain Gelsbro. Following 2 rinses with medium without serum $24 \mathrm{~h}$ post infection, the cultures were fixed for $15 \mathrm{~min}$ in either acetone or in $3 \%$ paraformaldehyde in $0.1 \mathrm{M}$ phosphate-buffered saline, $\mathrm{pH} 7.2$ (PBS) followed by $0.05 \%$ Triton X-100 in PBS for 30 min. The fixed cell cultures were stored at $-20^{\circ} \mathrm{C}$ until used. The coverglasses were then overlaid with $40 \mu \mathrm{l}$ of trout serum diluted 1:10 in PBS and incubated overnight at $4{ }^{\circ} \mathrm{C}$ in a humid chamber. Following a rinsing cycle $(2 \times 10 \mathrm{~min}$ in $0.85 \mathrm{M}$ aqueous $\mathrm{NaCl}$ with $0.05 \%$ Tween-20 followed by $1 \times 10 \mathrm{~min}$ in de-mineralized water with $0.05 \%$ Tween-20) $40 \mu \mathrm{l}$ of FITC- or TRITCconjugated rabbit Ig to trout immunoglobulin diluted 1:25 in PBS were added and the cultures incubated for $30 \mathrm{~min}$ at $37^{\circ} \mathrm{C}$. After another rising cycle, the coverglasses were mounted in PBS-buffered glycerol, $\mathrm{pH} 8$, and examined with an Olympus Vanox epifluorescence microscope equipped with a $200 \mathrm{~W}$ mercury lamp and with fluorescence oil objectives ( $\times 40$ and $\times 100$ ).

Enzyme-linked immunosorbent assay (ELISA). ELISA for detection of rainbow trout antibody to Egtved virus was performed using indirect ELISA as described by Voller et al. (1979): Microtitre plates (Maxisorp Nunc-ImmunoPlates, Teknunc, Denmark) were coated with purified rabbit anti-Egtved virus Ig diluted 1:200 in carbonate buffer ( $\mathrm{pH}$ 9.6) containing 15 $\mathrm{mM}$ sodium azide $(50 \mu \mathrm{l}=0.9 \mu \mathrm{g} \mathrm{Ig}$ in each well). The wells were sealed with parafilm and stored for a minimum of one night and a maximum of $2 \mathrm{wk}$ in a humid chamber at $4{ }^{\circ} \mathrm{C}$. The plates were then washed 3 times with PBS ( $\mathrm{pH} 7.2$ ) containing $0.05 \%$ Tween-20 (PBS-T) and incubated $1 \mathrm{~h}$ at $37^{\circ} \mathrm{C}$ or overnight at $4^{\circ} \mathrm{C}$ with Egtved virus strain Gelsbro in the form of $0.45 \mu \mathrm{m}$ filtered medium. The filtered medium was derived from cell cultures showing complete cytopathic effect (CPE) and had been diluted 1:5 in PBS-T with $1 \%$ bovine serum albumin (PBS-T-BSA). After 3 additional washings in PBS-T and blocking for $2 \mathrm{~h}$ at room temperature with PBS-T-BSA, the plates were incubated $1 \mathrm{~h}$ 
at $37^{\circ} \mathrm{C}$ with $50 \mu$ l per well of serial 2-fold dilutions (starting at 1:40) of trout serum in PBS-T-BSA. A positive and a negative control trout serum were used on each plate. During the last part of the work, trout serum in the same dilutions was also added to plates from which the virus antigen layer had been omitted. This procedure was adopted to identify trout sera which reacted with the capture antibodies and/or plastic surfaces, thereby giving false-positive reactions. After a repeated washing procedure, the trays were incubated for $1 \mathrm{~h}$ at $37^{\circ} \mathrm{C}$ with $50 \mu \mathrm{l}$ of HRP-conjugated rabbit Ig to rainbow trout immunoglobulin diluted 1:1000 in PBS-T-BSA $(0.2 \mu \mathrm{g}$ Ig per well). In some of the experiments, monoclonal antibodies (MAbs) to rainbow trout IgM were used instead of rabbit antibodies, and in those cases the incubation was followed by a washing procedure and incubation for $1 \mathrm{~h}$ at $37^{\circ} \mathrm{C}$ with HRPconjugated rabbit Ig to mouse Ig. In all cases, after renewed washing, the bound enzyme was visualized using $\mathrm{H}_{2} \mathrm{O}_{2}$-ortho-phenylenediamine substrate $(50 \mu \mathrm{l}$ well $\left.^{-1}\right)$. The colour reaction was stopped after $15 \mathrm{~min}$ using $1 \mathrm{M} \mathrm{H}_{2} \mathrm{SO}_{4}\left(100 \mu \mathrm{l}\right.$ well $\left.{ }^{-1}\right)$. Absorbance was measured spectrophotometrically in a Titertek Multiscan reader at a wavelength of $492 \mathrm{~nm}\left(\mathrm{~A}_{492}\right)$. The ELISA titre of a trout serum to Egtved virus was defined as the reciprocal value of the highest serum dilution giving an $\mathrm{A}_{492} \geq 0.50$. When the test was performed in trays with and without virus, respectively, the titre was defined as the reciprocal value of the highest serum dilution giving an $\mathrm{A}_{492}$-difference of 0.5 or more for reaction mixtures with and without Egtved virus.

\section{RESULTS}

\section{Sera from trout exposed to VHS under experimental conditions}

Examinations by ELISA and 50\% PNT indicated that sera with titres $\geq 40$ from trout exposed to VHS under experimental conditions should be regarded as positive because the titres of the pre-immune sera never exceeded this value. The kinetics of the antibody response to Egtved virus following exposure under experimental conditions was similar to that previously described (Olesen \& Jørgensen 1986a). Four weeks after infection, antibodies to Egtved virus could be detected in $32 \%$ of the fish by ELISA and in $23 \%$ of the fish by $50 \%$ PNT (Fig. 1A, B). The highest mean titre in both tests was observed $10 \mathrm{wk}$ after the initial exposure to the virus. The titre values reached about the same level in the 2 tests. No anamnestic immune response was detected by any of the 2 tests following a second virus challenge $14 \mathrm{wk}$ after the first exposure. None of the fish given a second virus challenge died or showed

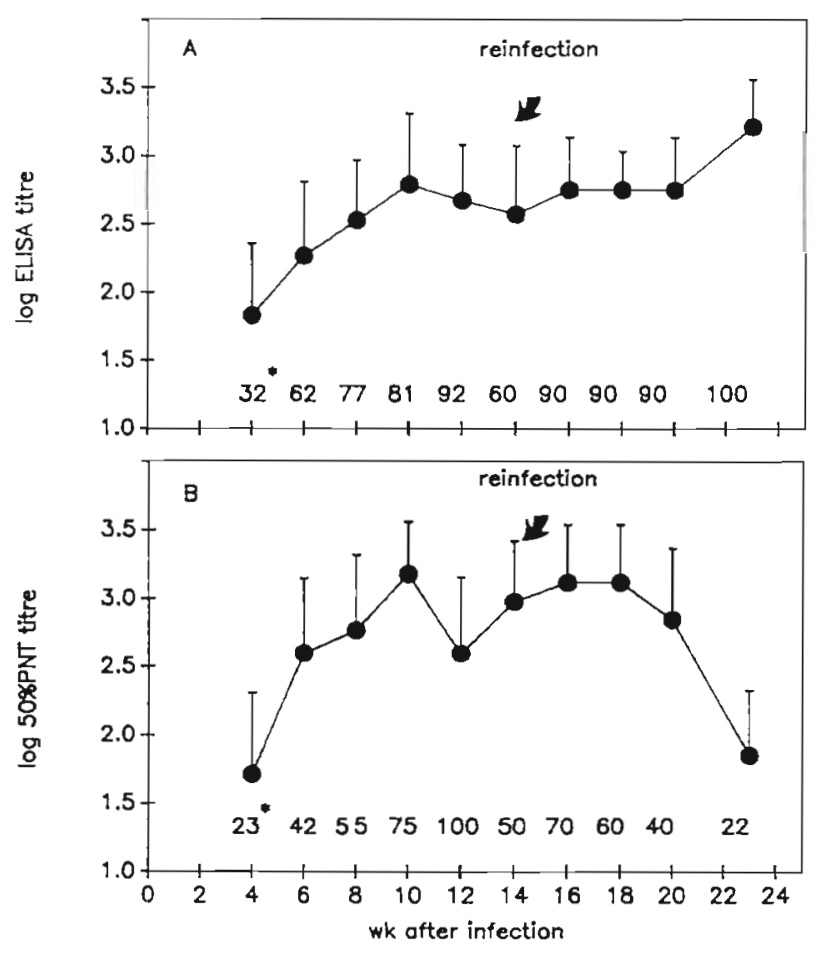

Fig. 1. Oncorhynchus mykiss. (A) ELISA titres and (B) plaque neutralization titres in sera from rainbow trout after VHSinfection by co-habitation and reinfection by injection. "Percent of sera with titres $\geq 40$. Vertical bars: standard deviation

any clinical signs of VHS. Between Weeks 18 and 23 after initial exposure, the mean 50\% PNT titre declined to 80 while the mean ELISA titre increased to more than 1280 .

When the ELISA used MAbs to detect trout IgM the same sensitivity and specificity as the above ELISA was obtained. The 2 techniques were compared on 33 trout serum samples only (data not shown).

All 80 serum samples from the 8 trout that survived the whole $23 \mathrm{wk}$ experimental period were examined by $50 \%$ PNT, ELISA, and by IF (Table 1). It seems that the development of antibodies detectable by means of IF largely parallelled the development of neutralizing antibodies and the antibodies detectable by means of ELISA. However, in the 4 and 6 wk samples, the highest sensitivity, in terms of number of positive samples, was observed with IF. In the 10 and 14 wk samples IF and ELISA appeared to be equally sensitive, and more sensitive than the $50 \%$ PNT. At 23 wk post infection, the ELISA revealed more positive samples than both IF and $50 \%$ PNT, with the 50\%PNT being the least sensitive technique of the three.

Sera that were considered positive in IF tests caused a bright cytoplasmic fluorescence of a granular type in the Egtved virus-infected cells as shown in Fig. 2. The intensity of the staining was considerably stronger in cell cultures fixed with paraformaldehyde-Triton X-100 
Table 1. Oncorhynchus mykiss. Antibody to Egtved virus detected by IFAT, ELISA and 50\% PNT, respectively, in 80 sera from 8 rainbow trout, each bled 10 times during a period of $23 \mathrm{wk}$ after VHS-infection by co-habitation under experimental conditions

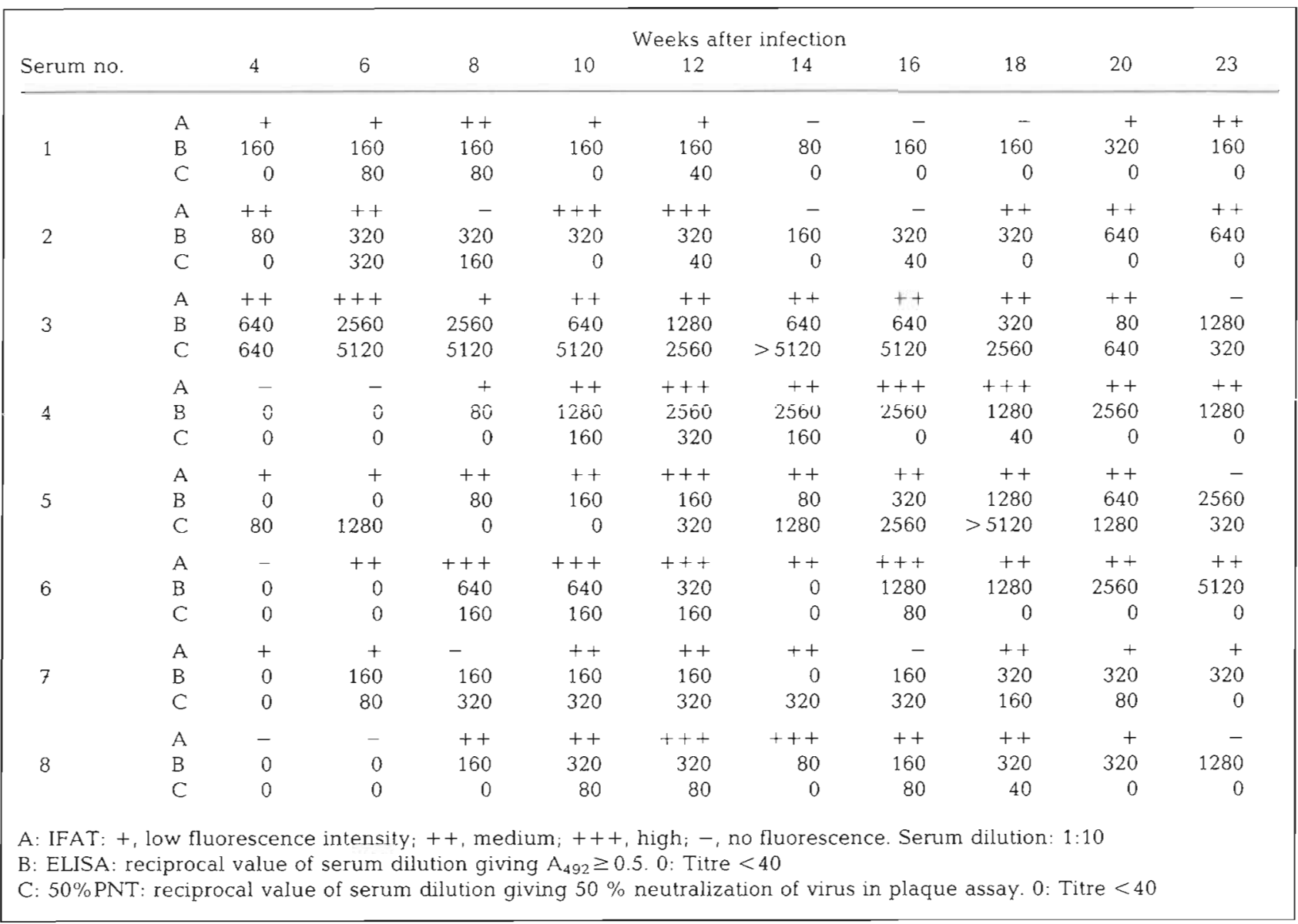

than in cultures fixed with acetone (not shown). None of the sera collected from the experimental fish before exposure to virus induced fluorescent staining in the cell cultures. Ten selected and strongly IF-positive sera were examined on cell cultures that had been inoculated with SVC virus instead of Egtved virus. In these cultures no fluorescence was observed. The FITC and the TRITC conjugates of rabbit Ig anti-rainbow trout IgM were found to be equally well suited for the present purpose, although the slower fading of TRITC was advantageous in some situations.

\section{Sensitivity and specificity of the 3 tests}

Sera collected before infection from the fish listed in Table 1 were negative in all of the 3 tests applied. Based on this, the test specificity in this experiment can be estimated to be 1.00 , i.e. there were no false-positive reactions. If only sera that were negative in all 3 tests are regarded as truly negative, 75 sera could be regarded as positive. Of these, 69 were positive in
ELISA, 64 in IF, and 45 in 50\%PNT, giving a test sensitivity of 0.92 in ELISA, 0.85 in IF, and 0.60 in $50 \%$ PNT, respectively (Martin et al. 1987).

\section{Sera from trout not exposed to VHS}

It was observed that some fish sera gave relatively high absorbance in ELISA in spite of the fact that they originated from trout farms with a well-documented history of freedom from VHS. It was not possible to reduce this reaction by using plasma instead of trout serum or by using MAbs to rainbow trout IgM instead of polyclonal rabbit antiserum (not shown). Table 2 shows the number of sera with titres of 40,80 , and 160 , respectively, among 289 sera collected in 7 VHS-free farms. Such sera were found with varying frequency in the different farms, i.e. in 0 to $48 \%$ of the examined fish. It appeared that $0.3 \%$ had a titre of $160,4.8 \%$ had titres of $\geq 80$, and $11.7 \%$ had titres of $\geq 40$. Using these values as the basis of a threshold for a positive reaction, it would appear that only titre values of $\geq 160$ should 
Fig. 2. Oncorhynchus mykiss. Immunofluorescence micrographs illustrating the staining of Egtved virus-infected EPC cells with rainbow trout anti-Egtved virus antiserum as the primary antibody. (A) $\times 370$; (B) $\times 880$
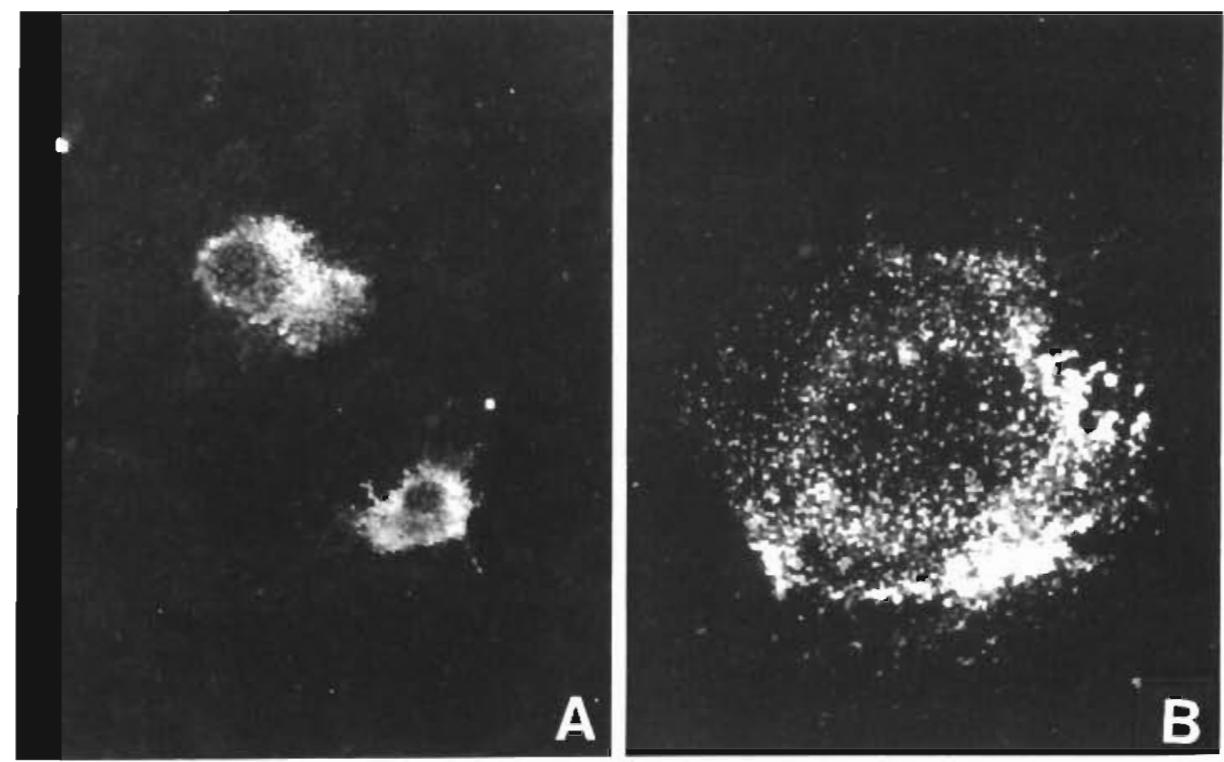

be regarded as positive (positivity definition 1). When ELISA-reactive sera from the VHS-free trout farms were examined in control wells in which the Egtved virus layer had been omitted, the $\mathrm{A}_{492}$ remained high. An example of this is given in Fig. 3 , where 3 sera from previously VHS-infected fish $(1,2,3)$ were compared with 2 sera from VHS-free fish $(4,5)$ in ELISA with and without Egtved virus. Antibodies in serum 4 still bound despite the omission of virus. This was true also for serum 3 which originated from a VHS-infected trout farm, illustrating that this type of non-specific reactivity can be observed regardless of VHS status. Because of this the 31 sera from VHS-free fish with ELISA titres $\geq$ 40 listed in Table 2 were examined in ELISA with and without Egtved virus. The difference in absorbance with and without virus in these sera never exceeded 0.4

Table 2. Oncorhynchus mykiss. Rainbow trout antibody to Egtved virus: ELISA titres in 289 sera originating from 7 VHSfree trout farms

\begin{tabular}{|lccccccc|}
\hline $\begin{array}{l}\text { Origin } \\
\text { of sera }\end{array}$ & No. of & \multicolumn{6}{c|}{ Sera with ELISA titre } \\
& sera & \multicolumn{2}{c|}{$\geq 160$} & \multicolumn{2}{c|}{$\geq 80$} & \multicolumn{2}{c|}{$\geq 40$} \\
& & No. & $\%$ & No. & $\%$ & No. & $\%$ \\
\hline A & 50 & 0 & 0 & 0 & 0 & 0 & 0 \\
B & 49 & 1 & 2 & 3 & 6 & 9 & 18 \\
C & 25 & 0 & 0 & 0 & 0 & 1 & 4 \\
D & 26 & 0 & 0 & 0 & 0 & 0 & 0 \\
E & 27 & 0 & 0 & 7 & 26 & 13 & 48 \\
F & 23 & 0 & 0 & 3 & 13 & 6 & 26 \\
G & 89 & 0 & 0 & 1 & 1 & 2 & 2 \\
Total & 289 & 1 & 0.3 & 14 & 4.8 & 31 & 10.7 \\
a ELISA titre: reciprocal value of highest serum dilution \\
giving $A_{492} \geq 0.5$
\end{tabular}

and consequently sera resulting in a 'virus-related $\mathrm{A}_{492}$ ', $\geq 0.5$ above the 'background $\mathrm{A}_{492}$ ' could be regarded as positive (positivity definition 2) (data not shown).

\section{Sera from trout exposed to VHS in infected trout farms}

When examined by means of ELISA, $54 \%$ of 115 sera collected in 4 different VHS-infected farms were found positive by definition 1 . In contrast, only $16 \%$ were positive, i.e. 160 or higher (Olesen \& Jørgensen 1986a) when they were examined by means of $50 \%$ PNT (Table 3). The distribution of the ELISA titres among the 115 sera examined is illustrated in Fig. 4. Most of the sera had titres in the range from 80 to 640 . In addition 49 of the sera were examined in the ELISA where the virus antigen layer had been omitted. This allowed application of positivity definition 2 which appeared to elevate the sensitivity of the test, because

Table 3. Oncorhynchus mykiss. Rainbow trout antibody to Egtved virus: $50 \%$ PNT and ELISA titres in 115 sera originating from 4 trout farms infected with VHS

\begin{tabular}{|c|c|c|c|c|c|}
\hline \multirow{2}{*}{$\begin{array}{l}\text { Origin } \\
\text { of fish }\end{array}$} & \multirow{2}{*}{$\begin{array}{l}\text { No. of } \\
\text { sera }\end{array}$} & \multirow{2}{*}{\multicolumn{2}{|c|}{$\begin{array}{c}50 \% \text { PNT } \geq 160^{\circ} \\
\text { No. } \quad \%\end{array}$}} & \multicolumn{2}{|c|}{ ELISA $\geq 160^{\circ}$} \\
\hline & & & & No. & $\%$ \\
\hline I & 40 & 0 & 0 & 16 & 40 \\
\hline II & 26 & 9 & 35 & 18 & 69 \\
\hline III & 24 & 0 & 0 & 8 & 33 \\
\hline IV & 25 & 9 & 36 & 20 & 80 \\
\hline Total & 115 & 18 & 16 & 62 & 54 \\
\hline \multicolumn{6}{|c|}{${ }^{a}$ No. of sera with $50 \%$ PNT titres $\geq 160$} \\
\hline
\end{tabular}



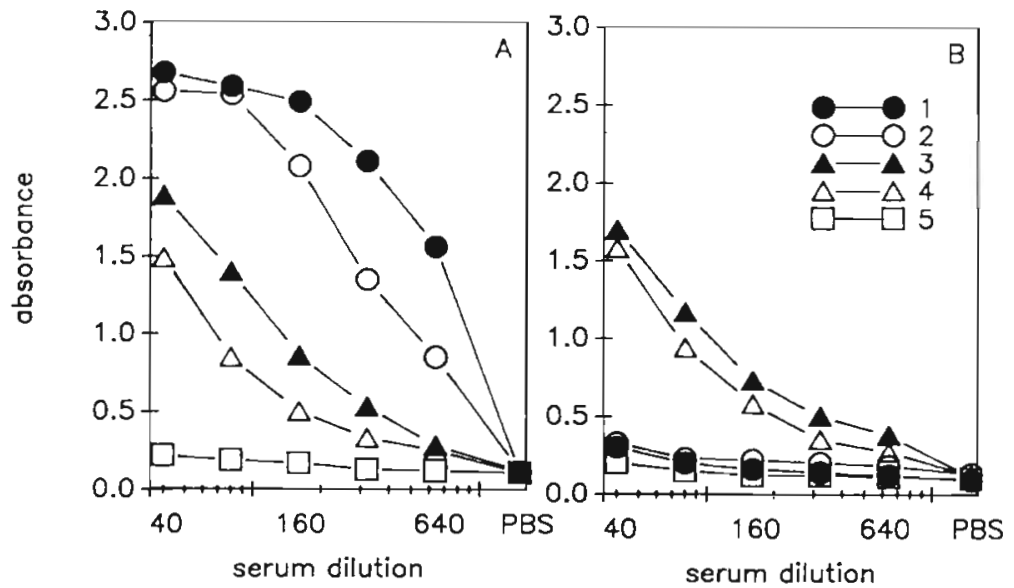

Fig. 3. Oncorhynchus mykiss. Absorbance values with 5 dilutions of rainbow trout sera in ELISA (A) with Egtved virus and (B) without Egtved virus. Trout sera from farms with VHS $(1,2,3)$ or with no VHS $(4,5)$ it now became possible to identify specific reactivity in serum dilutions below 160 . Whereas application of definition 1 yielded $57 \%$ positive sera, definition 2 yielded $67 \%$ positive sera (Table 4 ).

\section{DISCUSSION}

The main result of the present investigation was the development of an ELISA technique suitable for examination of large numbers of trout sera. The method was found to be more sensitive than either $50 \%$ PNT or IF. In addition, the costs of examination in terms of time and material consumption per sample were low compared to the other techniques.

A surprising finding was the occurrence of serum samples that reacted non-specifically in the ELISA test system, probably through adsorption of immunoglobulin to plastic surfaces or to non-viral proteins in the wells of the ELISA trays. The mechanisms underlying this non-specific reactivity as well as the reason for the

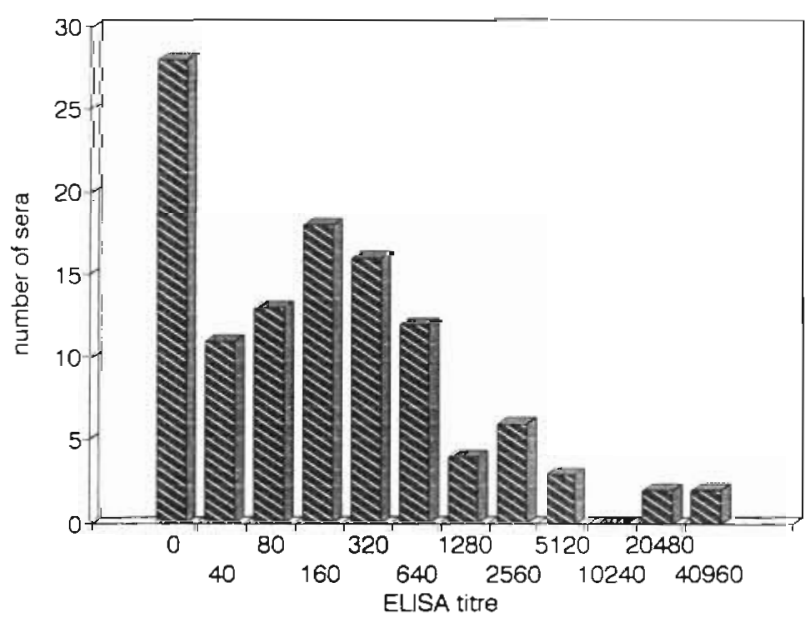

Fig. 4. Oncorhynchus mykiss. Distribution of ELISA titres in 115 rainbow trout sera from 4 VHS-infected trout farms varying frequency of such sera in different trout farms are unknown at present. Further investigations are needed to elucidate the possible influence on the above reactivity of parameters such as environmental factors, disease status with regard to diseases other than VHS, total Ig concentration in fish serum, and phenotypic characteristics in different fish stocks. The problem that might be caused by such sera in terms of false-positive reactions has been dealt with by means of one of the following 2 procedures: (1) only sera yielding $A_{492} \geq 0.5$ in dilution of $1: 160$ or more were considered positive (positivity definition 1); or (2) the sera were examined both in wells with and in wells without virus and only accepted as positive if the difference in absorbance between the two was 0.5 or more at serum dilution 1:40 or more (positivity definition 2). Definition 1 was based on the observation that sera from VHS-free farms very rarely reacted at titres of 160 or more. However, the fact that occasional serum samples from VHS-free farms yielded these titres made it necessary to interpret the result of serological screening of trout farms with some caution. Definition 2, which is now routinely used, turned out to be more satisfactory because it allowed titres as low as 40 to be considered positive through exclusion of false positive reactions. This added to the sensitivity and the specificity of the test and was espe-

Table 4. Oncorhynchus mykiss. Evaluation of ELISA reactions in 49 sera according to 2 different positivity definitions

\begin{tabular}{l}
\hline \multicolumn{2}{c|}{ Positive sera } \\
\hline
\end{tabular}


cially useful in situations where pre-immune serum samples were not available. The required difference in reactivity of 0.5 in definition 2 was based on the fact that all 289 sera examined from VHS-free rainbow trout had an absorbance/absorbance difference of less than 0.5 . This procedure to discriminate between positive and negative sera appeared to be the best suited one for our laboratory. If other laboratories wish to utilize the positivity 2 approach, they should determine the minimum absorbance difference in the wells with and without virus for their particular reagents before a serum is called positive. The use of an absolute absorbance value difference is not advised.

An important feature of the test is the use of purified Ig from rabbit antiserum to Egtved virus to capture the virus from crude virus preparations. By means of this procedure it was possible to avoid the very laborious purification of large quantities of virus which would have been needed in an ELISA in which virus is used in the first reagent layer in the plastic trays (CossariniDunier 1985, own obs.).

Among the 3 techniques tested, 50\% PNT turned out to be the least sensitive. This technique, in addition, suffers from the disadvantages of being time-consuming, technically difficult, and requiring VHS-antibodyfree trout complement (Olesen \& Jørgensen 1986a). On that basis, the technique is of limited use only. The theoretical basis for the reduced sensitivity of the $50 \%$ PNT is probably that one is measuring only those antibodies involved in neutralization (i.e. antibodies reacting with a few epitopes on the glycoprotein [Gprotein] of the virus) whereas techniques such as ELISA and IF allow detection of antibodies directed against any virus protein that is exposed to the reagents. This implies that ELISA and IF ought to be able to detect antibodies not only to the $\mathrm{G}$, but also to the $\mathrm{N}$, $M_{1}, M_{2}$ and $L$ proteins. Results of the present work indicate that non-neutralizing antibodies tend to persist in fish for a longer time than neutralizing antibodies (Fig. 1A, B). This appears to be a new and potentially important finding with regard to the understanding of the kinetics and complexity of the immune response of trout to VHSV infection.

IF had a sensitivity much higher than that of $50 \%$ PNT and close to that of ELISA. When examining sera taken a very short time after exposure to VHS the technique even seemed to be more sensitive than ELISA. This finding with IF is different from our earliest experience with the technique, which was that it did not allow detection of antibodies in trout exposed to natural infection with VHS (Jørgensen 1974). The improved sensitivity is primarily due to the use of better equipment, particularly the microscope, light source, and objectives, and also to the very advantageous use of paraformaldehyde-Triton-fixed instead of acetone- fixed cell cultures. Paraformaldehyde-Triton has been reported to be the least denaturating reagent for fixation of cell cultures for fluorescence microscopy (Biberfeld et al. 1974). Results demonstrating that IF was more sensitive than $50 \%$ PNT have already been reported (Olesen \& Jørgensen 1984). In that report the use of acetone-fixed cells, combined with the sequential use of 5 reagent layers, induced a strong amplification of the IF staining reaction. However, the procedure was time-consuming and so the technique was never routinely used. With the present techniques, IF is more time-consuming than ELISA but probably less so than $50 \%$ PNT. The microscopic examination of cell cultures, however, requires staff with special training to avoid misinterpretations, a fact which is well known for most IF techniques. On that basis IF cannot be considered well suited for examination of large numbers of trout sera. On the other hand, the technique is of some interest since it allows observations to be made with regard to the intracellular localization of antigen-antibody reactions. In some cases such information can give important hints as to the specificity of the detected antibodies. The IF technique is suitable for detailed examination of small numbers of experimental serum samples and for the checking of sera with questionable reactivity in ELISA.

None of the methods tested allowed detection of an anamnestic immune response following reinfection with VHS. Knowledge of such a response to pathogens is of value when vaccination strategies are being planned. These results, as well as previous findings with 50\% PNT (Olesen \& Jørgensen 1984), are in agreement with those of Cossarini-Dunier $(1985,1986)$ who found no anamnestic immune response in trout after booster injections of T-cell-dependent or -independent antigens.

\section{LITERATURE CITED}

Biberfeld, P., Biberfeld, G., Molnar, Z., Fagraeus, A. (1974) Fixation of cell-bound antibody in the membrane immunofluorescence test. J. Immunol. Meth. 4: 135-148

Cossarini-Dunier, M. (1985). Indirect enzyme-linked immunosorbent assay (ELISA) to titrate rainbow trout serum antibodies against two pathogens: Yersinia ruckeri and Egtved virus. Aquaculture 49:197-208

Cossarini-Dunier, M. (1986). Secondary response of rainbow trout (Salmo gairdneri Richardson) to DNP-haemocyanin and Yersinia ruckeri. Aquaculture 52: 81-86

Dorson, M., Torchy, C. (1979). Complement dependent neutralization of Egtved virus by trout antibodies. J. Fish. Dis 2: $345-347$

Fijan, N., Petrinec, Z., Sulimanović, D., Zwillenberg, L. O. (1971). Isolation of the causative agent from the acute form of infectious dropsy of carp. Vet. Arh. 41: 125-138 
Fijan, N., Sulimanović, D., Bearzotti, M., Muzinić, D., Zwillenberg, L. O., Chilmonczyk, S., Vautherot, J. F., de Kinkelin, P. (1983). Some properties of the epithelioma papulosurn cyprini (EPC) cell line from carp (Cyprinus carpio) Ann. virol. Inst. Pasteur 134 E: 207-220

Goding, J. W. (1986). Monoclonal antibodies: principles and practice, 2nd edn. Academic Press, London, p. 255-262

Jensen, M. H. (1965). Research on the virus of Egtved disease. Ann. N.Y Acad. Sci. 126: 422-426

Jorgensen, P. E. V. (1974). Indirect fluorescent antibody techniques for demonstration of trout viruses and corresponding antibody. Acta. Vet. Scand. 15: 198-205

Kinkelin, P. de, Bearzotti-Le Berre, M., Bernard, J. (1980). Viral haemorrhagic septicaemia of rainbow trout: selection of a thermoresistant virus variant and comparison of polypeptide synthesis with the wild type virus strain. J. Virol. 36: 652-658

Lorenzen, N., Olesen, N. J., Jørgensen, P. E. V. (1988). Production and characterization of monoclonal antibodies to four Egtved virus structural proteins. Dis. aquat. Org. 4: 35-42

Marin, S. W., Meek, A. H., Willeberg, P. (1987). Veterinary epidemiology: principles and methods, 1st edn. Iowa State University Press, Ames

Olesen, N. J., Jergensen, P. E. V (1984). Udvikling af mere

Responsible Subject Editor: Dr. I Evelyn, Nanaimo, B.C., Canada folsomme laboratoriemetoder til påvisning af virus og virusantistoffer i orreder udsat for smitte med Egtved virus årsagen til sygdommen VHS på dambrug. (Development of more sensitive methods for detection of virus and virus antibodies in trout exposed to infection with Egtved virus, the causative agent of VHS in trout farms.) Teknologirådet (Danish Academy of Technical Sciences). Rapport no 1982-133/001-82 390

Olesen, N. J., Jørgensen, P. E. V (1986a). Detection of neutralizing antibody to Egtved virus in rainbow trout (Salmo gairdneri) by plague neutralization test with complement addition. J. appl. Ichtyol. 2 (1): 33-41

Olesen, N. J., Jørgensen, P. E. V. (1986b). Quantification of serum immunoglobulin in rainbow trout (Salmo gairdneri) under various environmental conditions. Dis. aquat. Org. 1. $183-189$

Voller, A., Bidwell, D. E., Bartlett, A. (1979). The enzymelinked immunosorbent assay (ELISA). A guide with dusilacis of micropiate appiications. Dynatech Europe, Guernsey

Wolf, K., Gravell, M., Malsberger, R. G. (1966). Lymphocystis virus: isolation and propagation in centrarchid fish cell lines. Science 151: 1004-1005

Manuscript first received: February 12, 1990

Revised version accepted: September 27, 1990 